\title{
Retinal peripheral changes after LASIK
}

\author{
Alterações da retina periférica após LASIK
}

João Jorge Nassaralla Junior', Regina Cândido Ribeiro dos Santos², Belquiz Amaral Nassaralla

\begin{abstract}
PURPOSE: To better define the effect of laser in situ keratomileusis (LASIK) on myopic eyes and the risk and incidence of retinal complications after surgery.METHODS: In a prospective study, 200 eyes of 100 patients, 49 male and 51 female, with a mean age of 29.7 years, had a complete posterior pole examination before and at 1 week, 1,3 and 12 months after bilateral simultaneous LASIK for the correction of myopia. Mean spherical equivalent was -7.75D (range 1.00 to -17.25D). Before LASIK, preventive treatment was carried out on predisposing lesions to retinal complications, with laser photocoagulation. RE: Before surgery, the ophthalmic features were: 86 eyes ( $43 \%$ ) presented no peripheral abnormalities; 49 eyes $(24.5 \%)$ had lattice degeneration; 18 eyes $(9 \%)$, white without pressure; 5 eyes $(2.5 \%)$, white with pressure; $33(16.5 \%)$, oral chorioretinal degenerations; $6(3 \%)$, paving stone; $45(22.5 \%$, ) posterior vitreous detachment; $20(10 \%)$, retinal vitreous traction; and $12(6 \%)$,round holes. Comparing the incidence of ophthalmic features before and at one year after surgery, there was not a statistical significant difference $(\mathrm{P}>0.05)$. CONCLUSION: Although retinal pathologic conditions have been described as complications after LASIK, our data did not reveal a cause-effect relationship between the refractive error corrective procedure and retinal complications. The retinal changes found after LASIK in this series of patients, appear to reflect the predisposition of myopes. Both patient and doctor should be aware that, even after the refractive error correction, the risk of complications related to the myopic eye would persist.
\end{abstract}

Keywords: Keratomileusis, laser in situ/ adverse effects; Myopia/surgery; Retinal diseases/complications

\footnotetext{
'Professor associado da pós-graduação da FCS-UnB. Departamento de Retina e Vítreo do Instituto de Olhos de Goiânia - Goiânia - GO; Doutor em Ciências da Saúde pela UnB; Doutor em Oftalmologia pela UFMG;

${ }^{2}$ Professora associada da pós-graduação da FCS-UnB; Departamento de Oftalmologia do Hospital de Base de Brasília - Brasília - DF; Doutora em Oftalmologia pela UNIFESP;

${ }^{3}$ Departamento de Catarata, Córnea e Cirurgia Refrativa do Instituto de Olhos de Goiânia - Goiânia - GO; Doutora em Oftalmologia pela UFMG.
}

Trabalho realizado no Instituto de Olhos de Goiânia - Goiânia - GO

Presented in part as a scientific poster at the 2000 Annual Meeting of the American Academy of Ophthalmology, Dallas, Texas, USA. 


\section{INTRODUCTION}

$\boldsymbol{L}$ aser in situ keratomileusis has become increasingly popular over the past several years in treating myopia, astigmatism, and more recently, hyperopia ${ }^{(1-4)}$. There are few articles on vitreoretinal complications after LASIK. Many anecdotal case reports have been obtained from refractive surgeons and retinal consultants. The incidence of vitreoretinal complications appears to be quite low in the few series published ${ }^{(5-12)}$. Kim and $\mathrm{Jung}^{5}$ and Luna et al. ${ }^{6}$ reported a case of macular hemorrhage. Ozdamar et al. ${ }^{7}$ reported a case of bilateral retinal detachment (RD) associated with giant retinal tear. Stulting et al. ${ }^{(8)}$ and Ruiz-Moreno et al. ${ }^{(9)}$, respectively, found that RD occurred in $4(0.25 \%)$ of 1,554 eyes, and in $4(0.45 \%)$ of 878 patients. Arevalo et al. ${ }^{(10)}$, in their report of 29,916 eyes that underwent LASIK, described an incidence of $0.06 \%$ of vitreoretinal pathologies after LASIK for myopic patients, what is similar to the emetrope population and much lower than the incidence of RD in myopes in general. This low incidence could theoretically be explained by observer bias, short follow-up intervals, lack of a control group, and poor study design but is probable that the incidence of vitreoretinal complications after LASIK, is really low.

This study was conducted to better define the incidence and risks of retinal pathologic conditions after LASIK for the correction of myopia and to analyze if the exacerbation of the retinal abnormalities found in myopic patients is associated with the LASIK procedure itself.

\section{Methods}

In a prospective study, 200 myopic eyes of 100 patients, 49 male and 51 female, with a mean age of 29.77
Table 1

Group classification, spherical equivalent and number of eyes

\begin{tabular}{ccccc}
\hline Group & $\begin{array}{c}\text { Spherical } \\
\text { Equivalent }\end{array}$ & $\begin{array}{c}\text { Number } \\
\text { of Eyes (\%) }\end{array}$ & $\begin{array}{c}\text { Right } \\
\text { Eyes }\end{array}$ & $\begin{array}{c}\text { Left } \\
\text { Eyes }\end{array}$ \\
\hline 1 & -0.75 to -2.25 & $43(21.5 \%)$ & 16 & 27 \\
2 & -2.50 to -3.75 & $51(25.5 \%)$ & 32 & 19 \\
3 & -4.00 to -7.75 & $73(36.5 \%)$ & 37 & 36 \\
4 & -8.00 to -11.75 & $23(11.5 \%)$ & 10 & 13 \\
5 & -12.00 to -17.25 & $10(5 \%)$ & 5 & 5 \\
\hline
\end{tabular}

\pm 7.24 years (range, 20 to 55 yr.) underwent laser in situ keratomileusis from october 1998 to october 1999, at the Goiania Eye Institute.

Mean preoperative spherical equivalent refraction with cycloplegia was $-7.75 \mathrm{D}$ (range -0.75 to -17.25 ). According to the preoperative spherical equivalent, the eyes were divided into 5 groups: Group 1 , from -0.75 to 2.25D; Group 2, from -2.50 to -3.75D; Group 3, from -4.00 to -7.75D; Group 4, from -8.00 to -11.75D and Group 5, from -12.00 to -17.25 . There were 43 eyes $(21,5 \%)$ in Group 1; 51(25,5\%) in Group 2; $73(36,5)$ in Group 3; $23(11,5 \%)$ in Group 4; and $10(5 \%)$ in Group 5, (Table 1).

Inclusion criteria were: adult patients, stable myopia, unsuccessful attempt to wear contact lens, inability to wear spectacles because of severe psychological inhibition, spectacle best-corrected visual acuity of at least 20/150, normal cornea, no ocular pathology, no lid abnormalities, no previous ocular surgery, no other ocular surgery after LASIK and no general health problems. All patients had a complete posterior pole examination before and at 1 week, 1, 3 and 12 months after bilateral simultaneous LASIK for the correction of myopia. Patients who failed to at least one of the followup visits were excluded. Discontinuation of contact lens

Table 2

\section{Preoperative data}

\begin{tabular}{ccccc}
\hline Age & Number of & \multicolumn{2}{c}{ Spherical Equivalent (Mean \pm SD) } & P-value \\
\cline { 3 - 4 } & Patients & OD & OS & \\
\hline $20 \mid-25$ & 18 & $-4.85 \pm 1.71$ & $-4.94 \pm 1.89$ & 0.942 \\
25 - 30 & 26 & $-4.61 \pm 1.21$ & $-4.99 \pm 1.50$ & 0.691 \\
30 - 35 & 30 & $-4.69 \pm 0.94$ & $-4.85 \pm 1.05$ & 0.823 \\
35 - 40 & 23 & $-5.01 \pm 1.81$ & $-4.41 \pm 1.32$ & 0.583 \\
40 - - 55 & 3 & $-7.58 \pm 11.52$ & $-6.75 \pm 11.84$ & 0.839 \\
Total & 100 & $-4.86 \pm 0.65$ & $-4.86 \pm 0.66$ & \\
\hline
\end{tabular}


Table 3

Vitreoretinal pathologic conditions over time

\begin{tabular}{|c|c|c|c|c|c|c|c|c|c|c|}
\hline \multirow{3}{*}{ ClinicaI findings ( $\%$ ) } & & & \multicolumn{8}{|c|}{ Time after LASIK } \\
\hline & \multicolumn{2}{|c|}{$\begin{array}{l}\text { Before } \\
\text { LASIK }\end{array}$} & \multicolumn{2}{|c|}{1 week } & \multicolumn{2}{|c|}{1 month } & \multicolumn{2}{|c|}{3 months } & \multicolumn{2}{|c|}{12 months } \\
\hline & OD & OS & OD & OS & OD & $\mathbf{O S}$ & OD & $\mathbf{O S}$ & OD & OS \\
\hline No abnormalities & 48 & 38 & 48 & 38 & 48 & 36 & 47 & 35 & 47 & 34 \\
\hline Lattice degeneration & 25 & 24 & 24 & 24 & 24 & 26 & 25 & 28 & 26 & 29 \\
\hline WWP & 8 & 10 & 8 & 10 & 8 & 12 & 8 & 10 & 8 & 10 \\
\hline WP & 2 & 3 & 2 & 3 & 2 & 3 & 2 & 3 & 2 & 3 \\
\hline PVD & 22 & 23 & 23 & 26 & 25 & 28 & 27 & 29 & 28 & 29 \\
\hline RVT & 11 & 9 & 11 & 10 & 11 & 10 & 11 & 11 & 11 & 12 \\
\hline $\mathrm{OCD}$ & 15 & 18 & 15 & 18 & 15 & 18 & 15 & 17 & 14 & 17 \\
\hline Paving stone & 2 & 4 & 3 & 5 & 9 & 5 & 3 & 5 & 3 & 5 \\
\hline Round holes & 7 & 5 & 7 & 5 & 7 & 5 & 8 & 5 & 8 & 6 \\
\hline Vitreous haze & 0 & 0 & 0 & 0 & 0 & 1 & 0 & 1 & 0 & 1 \\
\hline
\end{tabular}

Table 4

Pathologic conditions before $\mathrm{X}$ one year after LASIK

\begin{tabular}{lccc}
\hline Pathologic Conditions & Before & After & P-value \\
\hline No abnormalities & $86(44 \%)$ & $81(40.5 \%)$ & 0.066 \\
Lattice degeneration & $48(24 \%)$ & $55(27.5 \%)$ & 1.0 \\
WWP & $18(9 \%)$ & $18(40.5 \%)$ & 1.0 \\
OCD & $33(16.5 \%)$ & $33(16.5 \%)$ & 1.0 \\
Paving stone & $8(4 \%)$ & $8(4 \%)$ & 1.0 \\
Round holes & $12(6 \%)$ & $14(7 \%)$ & 1.0 \\
WP & $5(2.5 \%)$ & $5(2.5 \%)$ & 1.0 \\
PVD & $49(24.5 \%)$ & $57(28.5 \%)$ & 0.754 \\
RVT & $21(10.5 \%)$ & $23(11.5 \%)$ & 0.158 \\
Vitreous haze & $0(0 \%)$ & $1(0.5 \%)$ & 0.066 \\
\hline
\end{tabular}

$\mathrm{WWP}=$ white without pressure $\mathrm{OCD}=$ oral chorioretinal degeneration; $\mathrm{WP}=$ white with pressure; $\mathrm{PVD}=$ posterior vitreous detachment; $\mathrm{RVT}=$ retinal vitreous traction

wear (if there was any) at least 2 weeks prior to preoperative evaluation and surgery was required.

All patients had a preoperative UCVA lower than 20/30 and a BSCVA of at least 20/150 (range 20/150 to 20/20).

The majority of patients ( $55 \%$ ) were between 25 to 35 years of age and presented moderate myopia. Only 3 patients $(1.5 \%)$ were between 40 to 55 years of age (Table 2).

There was not a statistically significant difference in preoperative spherical equivalent between eyes $(\mathrm{p}>0.05)$ (Table 2).
Before surgery, informed consent was obtained from all patients after they received a detailed description of the surgical procedure and its known risks.

Preoperative examination included personal medical ocular history, uncorrected visual acuity (UCVA), best spectacle corrected visual acuity (BSCVA), corneal topography, keratometry, ultrasonic pachymetry, manifest and cycloplegic refraction, tonometry, slit-lamp microscopy, specular microscopy, and a comprehensive posterior pole examination. Binocular indirect ophthalmoscopy was performed with 360degree scleral depression and fundus biomicroscopy, with 
Goldman's $67^{\circ}$ mirror. All detected lesions predisposing to retinal detachment were treated with photocoagulation before LASIK and followed by a complete fundus examination.

All patients were premedicated with a mild oral sedative (diazepam $5 \mathrm{mg}$ ) 30 minutes before surgery and two drops of topical $0.5 \%$ proparacaine 2 to $5 \mathrm{~min}$ utes before surgery. A sterile plastic ophthalmic drape and a wire speculum respectively draped and separated the eyelids to prepare for the procedure. A heavily marked cornea helped insure good postoperative flap alignment. The suction ring was applied and the intraocular pressure was checked with the Barraquer tonometer to ensure that it was in the appropriate range of approximately $65 \mathrm{mmHg}$.

Patients were treated with the Chiron Technolas 217 excimer laser (Bausch \& Lomb, Claremont, USA). The laser was calibrated with the following parameters: duration 18ns/pulse; ablation range, $0.25 \mu \mathrm{m} /$ pulse; fluence, $120 \mathrm{~mJ} / \mathrm{cm} 2$; repetition frequency, $50 \mathrm{~Hz}$; wavelength, $193 \mathrm{~nm}$. The optical zone and ablation depth was determined by the software program.

We used the automated corneal shaper (ACS, Bausch \& Lomb, Claremont, USA) to create a corneal flap of about $8.5 \mathrm{~mm}$ diameter with a nasal hinge and thickness of $160 \mu \mathrm{m}$. The ACS is equipped with a mechanical stop that automatically leave a small hinge nasally. The corneal flap was manually reflected nasally with a blunt spatula. We then asked the patient to fixate the coaxial HeNe light of the laser. Next, the laser was focused with the green focusing beam and centered over the middle of the entrance pupil. Once centered, the eye was illuminated with a special infrared light source and the eye tracker was engaged. With the help of the eye tracker, the position of the pupil can be determined and the laser beam can track the movements of the eye during laser treatment. This device reduces decentration. The treatment was then started. To avoid damage of the flap, the hinge and back of the flap were covered with a Merocel sponge.

The excimer laser ablation was performed in the stromal bed. After the ablation was completed, suction was discontinued and the stromal bed carefully irrigated and cleaned of debris using balanced salt solution. The flap was then repositioned carefully without sutures. We waited 3 minutes before two tobramicin-dexamethasone drops were instilled into the cul-de-sac.

At the end of the operation, a protective transparent shield was placed over the eye and secured with surgical tape. No patching was used. The following day, the shield was removed and the eye was examined.
Tobramycin sulfate $0.3 \%$ and dexamethasone sodium phosphate $0.1 \%$ drops were prescribed four times daily for 1 week beginning immediately after surgery. Unpreserved artificial tears were recommended for mild irritation.

All LASIK procedures were performed by the same refractive surgeon (BRAN) and all posterior segments examinations and treatments were performed by the same retinal specialist (JJNJ) before surgery and at 1 week, 1, 3 and 12 months after bilateral simultaneous LASIK.

Postoperative examinations included: uncorrected visual acuity, best corrected visual acuity, manifest refraction, ultrasonic pachymetry, corneal topography, complete anterior segment evaluation, binocular indirect ophthalmoscopy with 360-degree scleral depression and fundus biomicroscopy with Goldman's $67^{\circ}$ mirror.

\section{RESULTS}

All patients were followed for at least 1 year.Table 3 shows our patients' vitreoretinal pathologic conditions over time and Table 4 compares its incidence before and 1 year after LASIK. Before surgery, the ophthalmic features were: 86 eyes (43\%) presented no peripheral abnormalities; 49 eyes $(24.5 \%)$ had lattice degeneration; 18 eyes (9\%), white without pressure (WWP); 5 eyes $(2.5 \%)$ white with pressure (WP); $45(22.5 \%)$ posterior vitreous detachment (PVD); 20 (10\%) retinal vitreous traction (RVT); $33(16.5 \%)$ oral chorioretinal degenerations (OCD); 6 (3\%) paving stone and 12 $(6 \%)$ round holes.

No eyes experienced intraoperative complications. Biomicroscopy and indirect ophthalmoscopy with scleral depression under pupillary dilation were performed to identify vitreoretinal pathologic conditions after LASIK.

Twelve months after surgery, some retinal pathologic conditions developed in $3.5 \%$ of the eyes considered normal before LASIK. Table 4 shows that lattice degeneration, round holes, posterior vitreous detachment, vitreous traction and vitreous haze were found, respectively in 7,2 and 8,2 and 1 new cases. Although the development of these cases, comparisons between the incidences of these ophthalmic features found before and at one year after surgery did not show a statistically significant difference $(p>0.05)$. No retinal detachment occurred in this series of patients.

Before surgery, the proportion of posterior vitreous detachment was higher in groups 4 and 5, with a statistically significant difference when compared to group 
3 , the one with the lower incidence $(\mathrm{p}<0.05)$. Retinal vitreous traction was proportionally more frequent in group 4 but statistically it was not different from the incidence found in groups 2 and 3 ( $p>0.05$ ). Group $5 \mathrm{did}$ not present any case of vitreous traction and group1, just one case. Group 3 presented the highest incidence of lattice degeneration and group 5, the lowest, with a significant difference between these two groups $(\mathrm{P}=0)$; although, groups 1,2 and 4 presented similarity to group 3 ( $p>0.05)$. Oral chorioretinal degeneration was more frequent in group 4 when compared to all other groups $(\mathrm{p}<0.05)$. Other clinical findings, although less frequent, were more incident in groups with higher degrees of myopia (Table 3).

One year after LASIK, comparison between groups showed that the higher the degree of myopia, the higher the incidence of posterior vitreous detachment $(p<0.05)$. Before surgery, the incidence of posterior vitreous detachment was statistically different between groups 3 and $4(\mathrm{P}=0.019)$; twelve months after LASIK, this difference was not significant anymore $(\mathrm{P}=0.174)$. Regarding retinal vitreous traction, comparison between groups before and at one year after surgery did not present any statistically significant difference.

Lattice degeneration was still proportionally more frequent in group 3 and less in group $5(\mathrm{P}=0)$. Its incidence in groups 1 and 2 , similar to group 3 before surgery, presented a statistically significant difference $(\mathrm{p}<0.05)$ one year after LASIK. Group 4 was still similar to group 3 ( $p>0.07$ ) with the highest incidence of this pathologic condition. Statistical analysis showed that the incidence of oral chorioretinal was similar in groups 4 and 5; groups 1,2 and 3 were similar to group 5 ( $p>0.05$ ) but still significantly different when compared to group 4.

Although new cases of other clinical findings occurred after surgery, their incidence was still higher in groups with higher degrees of myopia with no statistically significant changes.

The incidence of vitreoretinal pathologic conditions after LASIK determined in our study was 2.5\% (5/ 200). All new detected lesions predisposing to retinal detachment were treated with photocoagulation after LASIK and followed by a complete fundus examination.

\section{Discussion}

In 1990, Pallikaris et al. ${ }^{(1)}$ proposed the corneal flap technique for laser in situ keratomileusis. The method is based on a lamellar cut, producing a corneal flap that is usually $160 \mu \mathrm{m}$ thick. Subsequent ablation of the corneal stroma is done using the excimer laser. Some studies have shown that, retinal detachment, retinal breaks, giant retinal tears, proliferative vitreoretinopathy, macular hemorrhage and vitreous hemorrhage have been described as complications after LASIK ${ }^{(5-16)}$.

To obtain a consistent flap of optimal thickness, the cornea is stabilized and made rigid by a suction ring that is placed just behind the limbus and that uses vacuum to increase the pressure and stabilize the anterior segment and the cornea. Some authors ${ }^{(7,10,11,15)}$ have proposed that, when the suction ring induces an increase in intraocular pressure (IOP), the anterior segments shape may change rapidly. Structures posterior to the suction ring are also compressed and decompressed in sequence. This "trauma" may displace the intraocular structures forward along with the anterior hyaloid. This might accelerate vitreous detachment or cause traction at the vitreous base. When the suction is released, decompression may produce a dynamic overshoot with equatorial expansion and shortening in the anteroposterior dimension, causing acute vitreoretinal traction at the vitreous and posterior pole. This could be a possible mechanism for development of peripheral retinal tears or macular injury ${ }^{(10,1415)}$.

Another possible mechanism for developing peripheral retinal pathologies following LASIK, was described by Charles ${ }^{(11,14-15)}$. Laser-tissue interaction creates acoustic pressure waves, which propagate through vitreous and theoretically could cause retinal breaks. The concave surface of the ocular interior will focus the acoustic energy, significantly increasing local acoustic power density.

Peripheral degeneration in myopic patients is common. Recent studies ${ }^{(12-15)}$ have described that in myopic eyes, asymptomatic retinal breaks occur in approximately $7 \%$ of patients over age 40 , and lattice degeneration is present in approximately $8 \%$ of the general population.

Posterior vitreous detachment in myopic eyes and peripheral retinal degenerations are predisposing factors for retinal detachment ${ }^{(1416)}$.Changes in intraocular pressure have been implicated as a cause of posterior vitreous detachment in myopic eyes ${ }^{(17)}$. The same mechanism has been implicated in the case of bilateral retinal detachment after laser in situ keratomileusis ${ }^{(7,15)}$.

Lattice degeneration is frequently associated with retinal detachment, occurring in approximately $20 \%$ of the patients with retinal detachment ${ }^{(15,1)}$. It was described in $6-20 \%$ of the myopic eyes. Four percent of the surgeons recommend treatment of lattice degeneration with holes, before cataract surgery ${ }^{(19)}$. Seventeen percent recommend prophylactic therapy in lattice degeneration 
with holes, despite evidence that the course of lattice degeneration is usually not influenced by the presence of holes within lattice lesions ${ }^{(19)}$. Byer ${ }^{(18)}$ observed $16.3 \%$ of atrophic holes in his clinical study. The nature and significance of white without pressure remains controversial.

Retinal Detachment occurs in 1:10.000 per year in general population ${ }^{(14-15,20)}$. Approximately $40-55 \%$ of retinal detachments affect myopic patients. ${ }^{(21)}$ Ogawa and Tanaka $^{13}$ analyzed 1,116 cases of retinal detachment and found that myopia was present in $82,16 \%$. Statically, myopes have a probability of having $2.4 \%$ of retinal detachment and emetropes, only $0.06 \% .{ }^{(13-15)}$ There is a relationship between the severity of myopia and the frequency of retinal detachment. In myopia higher than $-15,00 \mathrm{D}$, the frequency of RD was 68,6 times higher than for the hyperopic range ${ }^{(13)}$. Most myopes have increased axial length; vitreous and peripheral fundus abnormalities in myopic eyes are the major factors that predispose to $\mathrm{RD}^{(1415,21)}$. Myopes undergo LASIK in ever increasing numbers and myopes are predisposed to retinal detachment as well as to macular hemorrhage and other macular pathologies.

The degree of myopia seems to be an important factor in the incidence of pathologic conditions, i.e, the higher the degree of myopia, the higher the incidence of posterior pole pathologic conditions.

In our series, we found 45 eyes $(22.5 \%)$ with posterior vitreous detachment before surgery and 57 ( $28.5 \%$ ) one year after LASIK, but no patient presented retinal detachment. The incidence of vitreoretinal pathologic conditions after LASIK determined in our study was $2.5 \%(5 / 200)$. This number is similar to the incidence of retinal detachment in myopia in general (1\%-3\% $)^{(10.14)}$ This finding is probably explained by the fact that our refractive surgery patient underwent complete preoperative examinations and all detected lesions predisposing to retinal detachment were treated with photocoagulation before LASIK. This prophylactic treatment of retinal peripheral lesions may probably be responsible for the absence of retinal detachment in this series of patients.

Posterior pole examination of the eyes that underwent laser in situ keratomileusis, was not difficult. In our series, the diameter of the laser ablation was 6 $\mathrm{mm}$, and indirect image from the peripheral retina or from the posterior pole was similar to those eyes without previous ocular surgery ${ }^{(14-15)}$.

Although some reports have appeared concerning retinal detachment after LASIK, our data did not reveal a cause-effect relationship between the refractive error corrective procedure and retinal complications. The association between retinal pathologic conditions and previous LASIK seems to reflect the predisposition of myopes. Any retinal lesions predisposing the eye to the development of retinal detachment should be treated before LASIK ${ }^{(14-15)}$.

\section{Conclusion}

LASIK appears to be safe to retina, with a low incidence of retinal peripheral changes. It is very important to inform patients that LASIK only corrects the refractive aspect of myopia; the risk of complications related to the myopic eye will persist. A long-term follow-up of these patients is important to confirm our findings.

\section{Resumo}

Objetivo: Definir melhor o efeito da técnica laser in situ keratomileusis (LASIK) em olhos míopes, o risco e a incidência de complicações retinianas após a cirurgia. Este estudo foi realizado no Instituto de Olhos de Goiânia. Métodos: Em um estudo prospectivo, 200 olhos de 100 pacientes, 50 homens e 50 mulheres, com idade média de 26,5 anos, foram submetidos ao exame completo do pólo posterior, antes e após 1 semana, 1,3 e 12 meses do LASIK bilateral simultâneo para a correção de miopia. A média do equivalente esférico foi-7,75D (variando entre -1,00 $a-17,25 D)$. Tratamento profilático foi realizado em lesões predisponentes a complicações retinianas, com fotocoagulação a laser, antes do LASIK. Resultados: Antes da cirurgia, as características oftalmoscópicas foram: 86 olhos (43\%) não apresentavam nenhuma anormalidade periférica; 49 olhos $(24,5 \%)$ apresentavam degeneração em paliçada; 18 olhos (9\%), branco sem pressão; 5 olhos (2,5\%), branco com pressão; 33 (16,5\%), degeneração orocoroidal; 6 (3\%), degeneração pavimentosa; $45(22,5 \%$, ) descolamento de vítreo posterior; $20(10 \%)$, tração vítreo-retiniana; e 12 (6\%), buracos retinianos. Comparando a incidência de características oftalmoscópicas antes e um ano após a cirurgia, não houve diferença estatisticamente significativa $(p>0.05)$. Conclusão: Embora condições patológicas da retina tenham sido descritas como complicações após o LASIK, nossos dados não revelaram uma relação de causa-efeito entre o procedimento para correção do erro refrativo e complicações retinianas. As alterações retinianas encontradas após o LASIK, nesta série de pacientes, parecem refletir a predisposição natural dos míopes. Paciente e cirurgião devem estar atentos aos riscos de complicações 
relacionadas aos olhos míopes, que persistem mesmo após o LASIK.

Descritores: Ceratomileuse assistida por excimer laser in situ/efeitos adversos; Miopia/cirurgia; Doenças retinianas/complicações

\section{References}

1. Pallikaris IG, Papatzanaki ME, Stathi EZ, Frenschock O, Georgiadis A. Laser in-situ keratomileusis. Lasers Surg Med. 1990; 10(5):463-8.

2. Nassaralla BA, Nassaralla JJ. Laser in situ keratomileusis after penetrating keratoplasty. J Refract Surg. 2000; 16(4):431-7.

3. Ibrahim O. Laser in situ keratomileusis for hyperopia and hyperopic astigmatism. J Refract Surg 1998; 14(2 Suppl): S179-82.

4. Pallikaris IG, Siganos DS. Laser in situ keratomileusis to treat myopia: early experience. J Cataract Refract Surg. 1997; 23(1):39-49.

5. Kim HM, Jung HR. Laser assisted in situ keratomileusis for high myopia. Ophthalmic Surg Lasers. 1996;27(5 Suppl):S508-11.

6. Luna JD, Reviglio VE, Juárez CP. Bilateral macular hemorrhage after laser in situ keratomileusis. Graefes Arch Clin Exp Ophthalmol. 1999;237(7):611-3.

7. Ozdamar A, Aras C, Sener B, Oncel M, Karacorlu M. Bilateral retinal detachment associated with giant retinal tear after laser-assisted in situ keratomileusis.Retina. 1998;18(2):176-7.

8. Stulting RD, Carr JD, Thompson KP, Waring GO 3rd, Wiley WM, Walker JG. Complications of laser in situ keratomileusis for the correction of myopia. Ophthalmology. 1999;106(1):13-20.

9. Ruiz-Moreno JM, Pérez-Santonja JJ, Alió JL. Retinal detachment in myopic eyes after laser in situ keratomileusis. Am J Ophthalmol. 1999;128(5):588- 94.

10. Arevalo JF, Ramirez E, Suarez E, Morales-Stopello J, Cortez $\mathrm{R}$, Ramirez $\mathrm{G}$,et al.Incidence of vitreoretinal pathologic conditions within 24 months after laser in situ keratomileusis. Ophthalmology. 2000;107(2:258-62.

11. Charles S. Vitreoretinal complications of refractive surgery. In: Boyd BF, editor. LASIK and Beyond LASIK. USA: Highlights of Ophthalmology;2001. p. 317.
12. Wilkinson CP. Evidence-based analysis of prophylactic treatment of asymptomatic retinal breaks and lattice degeneration. Ophthalmology. 2000;107(1):12-5; discussion 15-8.

13. Ogawa A, Tanaka M. The relationship between refractive errors and retinal detachment-analysis of 1,166 retinal detachment cases. Jpn J Ophthalmol. 1988;32(3):310-5.

14. Alterações retinianas após LASIK - 4 anos de Follow Up Rev Soc Bras Retina Vítreo. 2006;10(1):16-20.

15. Nassaralla Jr JJ, Nassaralla BA. Degenerações periféricas da retina do olho míope x LASIK. Arq Bras Oftalmol. 2004;67(2):353-8.

16. Burton TC. The influence of refractive errors and lattice degeneration on the incidence of retinal detachment. Trans Am Ophthalmol Soc. 1990; 87:143-55 ; discussion 155-7.

17. Alió JL, Ruiz-Moreno JM, Artola A. Retinal detachment as a potential hazard in surgical correction of severe myopia with phakic anterior chamber lenses. Am J Ophthalmol. 1993;115(2):145-8. Erratum in: Am J Ophthalmol. 1993;115(6):831

18. Byer NE. Long-term natural history of lattice degeneration of retina. Ophthalmology 1989: 96(9 ):1396-401; discussion 1401-2.

19. Byer NE. Lattice degeneration of the retina. Surv Ophthalmol. 1979; 23(4): 213 - 48.

20. Benson WE, Morse PH. The prognosis of retinal detachment due to lattice degeneration. Ann Ophthalmol. 1978; 10(9): 1197-2000.

21. Curtin BJ. The myopias: Basic and Clinical Management. Philadelphia: Harper \& Row; 1985. p.337- 9.

ENDEREÇO PARA CORRESPONDÊNCIA:

João J. Nassaralla Jr, MD

Instituto de Olhos de Goiânia

Rua $L, n^{\circ} 53 \# 12^{\circ}$ andar, Setor Oeste,

ZC: 74.120-050 - Goiânia, Goiás - Brasil,

Phone: 55 (62) 3220-2511; Fax: 55 (62) 3220-2560;

E-mail: nassaral@zaz.com.br 